\title{
HUBUNGAN ANTARA KOMPETENSI PEDAGOGIK DAN KINERJA GURU DI KECAMATAN GIRIMULYO KABUPATEN KULON PROGO
}

\author{
Oleh: \\ ${ }^{1}$ Fransisca Valeria Sunartini, dan ${ }^{2}$ Triana Noor Edwina Dewayani Soeharto \\ ${ }^{1,2}$ Fakultas Psikologi Universitas Mercu Buana Yogyakarta \\ e-mail : ${ }^{1}$ fransisca_valeria@yahoo.com, ${ }^{2}$ winasoeharto@gmail.com
}

\begin{abstract}
ABSTRAK
Tujuan penelitian ini adalah : (1) untuk mengetahui hubungan antara kompetensi pedagogik dan kinerja guru. Populasi penelitian ini adalah guru SD di Unit Pelaksana Teknis Daerah Pendidikan Anak Usia Dini dan Pendidikan Dasar Kecamatan Girimulyo Kabupaten Kulon Progo. Sampel penelitian diambil dengan teknik kelompok sampel, dengan sampel berjumlah 40 orang. Alat ukur yang digunakan, yaitu skala kompetensi pedagogik dan skala kinerja guru. Teknik analisa data menggunakan uji statistik korelasi product moment. Hasil penelitian menunjukkan bahwa: (1) ada hubungan yang signifikan dan positif antara kompetensi pedagogik guru dan kinerja guru SD di Unit Pelaksana Teknis Daerah Pendidikan Anak Usia Dini Dan Pendidikan Dasar Kecamatan Girimulyo Kabupaten Kulon Progo.
\end{abstract}

Kata Kunci: kompetensi pedagogik, kinerja guru, sekolah dasar.

\section{PENDAHULUAN}

\section{UPTD PAUD dan DIKDAS}

Kecamatan Girimulyo mempunyai sumber daya manusia yang terdiri dari Kepala Sekolah, Guru, dan Tenaga Kependidikan yang terinci sebagai berikut: 21 orang Kepala Sekolah yang terdiri dari 18 orang Kepala Sekolah Negeri dan 3 orang Kepala Sekolah Swasta , 102 orang guru kelas, 17 guru Pendidikan Agama Islam, dan 1 guru Pendidikan Agama Katolik. UPTD PAUD dan DIKDAS Kecamatan Girimulyo terdiri dari 21 satuan pendidikan tingkat SD.

Menurut Joni (1980) jabatan guru merupakan jabatan profesional, dan sebagai jabatan profesional, pemegangnya harus memenuhi kualifikasi tertentu. Kriteria jabatan profesional antara lain bahwa jabatan itu melibatkan kegiatan intelektual, mempunyai batang tubuh ilmu yang khusus, memerlukan persiapan lama untuk memangkunya, memerlukan latihan dalam jabatan yang berkesinambungan, merupakan karier hidup dan keanggotaan yang permanen, menentukan baku perilakunya, mementingkan layanan, mempunyai organisasi profesional, dan mempunyai kode etik yang ditaati oleh anggotanya.

Menurut Supriyadi (1998) istilah profesionalisme merujuk pada derajat penampilan individu sebagai seorang 
professional atau penampilan suatu pekerjaan sebagai suatu profesi. Oleh karenanya dapat dimaknai sebagai mutu, kualitas, dan tindak-tanduk yang merupakan ciri suatu profesi atau orang yang profesional, atau sifat profesional. Profesionalisme itu berkaitan dengan komitmen para penyandang profesi. Untuk meningkatkan kemampuan profesionalnya secara terus menerus, mengembangkan strategi-strategi baru dalam tindakannya melalui proses pembelajaran yang terus menerus pula. Profesionalitas guru yang ditunjukkan dengan kinerja guru dapat dikatakan sebagai kunci keberhasilan pendidikan.

Menurut UU No. 20 Tahun 2003 dan UU No. 14 Tahun 2005, kinerja guru merupakan rumusan dalam melaksanakan tugas utama dan menunaikan beban kerja serta mewujudkan kompetensi dalam mengemban amanah pendidikan yang ada di pundaknya. Menurut Sanjaya (2005), kinerja guru berkaitan dengan tugas perencanaan, pengelolaan pembelajaran, dan penilaian hasil belajar siswa.

Menurut Badan Pengembangan Sumber Daya Manusia, Pendidikan dan Kebudayaan Penjamin Mutu Pendidikan (2012), karakeristik kinerja guru meliputi perencanaan guru dalam pembelajaran, pelaksanaan kegiatan pembelajaran yang aktif dan efektif, dan penilaian pembelajaran. Perencanaan pembelajaran meliputi: guru memformulasikan tujuan pembelajaran dalam RPP sesuai dengan kurikulum/silabus dan memperhatikan karakteristik peserta didik, guru menyusun bahan ajar secara runut, logis, kontekstual dan mutakhir, guru merencanakan kegiatan pembelajaran yang efektif, guru memilih sumber belajar/ media pembelajaran sesuai dengan materi dan strategi pembelajaran.

Pelaksanaan kegiatan pembelajaran yang aktif dan efektif meliputi: guru memulai pembelajaran dengan efektif, guru menguasai materi pelajaran, guru menerapkan pendekatan/strategi pembelajaran yang efektif, guru memanfaatan sumber belajar/media dalam pembelajaran, guru memicu dan/atau memelihara keterlibatan siswa dalam pembelajaran, guru menggunakan bahasa yang benar dan tepat dalam pembelajaran, guru mengakhiri pembelajaran dengan efektif.

Penilaian pembelajaran meliputi : (a) guru merancang alat evaluasi untuk mengukur kemajuan dan keberhasilan belajar siswa, (b) guru menggunakan berbagai strategi dan metode penilaian untuk memantau kemajuan dan hasil belajar siswa dalam mencapai kompetensi tertentu sebagaimana yang tertulis dalam RPP, dan (c) guru memanfatkan berbagai 
hasil penilaian untuk memberikan umpan balik bagi siswa tentang kemajuan belajarnya dan bahan penyusunan rancangan pembelajaran selanjutnya.

Rivai (2004) menjelaskan bahwa kinerja guru adalah perilaku nyata yang ditampilkan oleh guru sebagai prestasi kerja berdasarkan standar yang ditetapkan dan sesuai dengan perannya di sekolah. Berdasarkan uraian di atas, dapat disintesiskan kinerja guru adalah hasil atau wujud dari segenap daya upaya yang berkenaan dengan segala macam tugas dan kewajiban yang harus dilakukan dan menyempurnakannya sesuai dengan tanggung jawab dalam mencapai tujuan yang diharapkan oleh sekolah.

$$
\text { Menurut Mulyasa }
$$

kompetensi pedagogik adalah seperangkat kemampuan dan keterampilan yang berkaitan dengan interaksi belajar mengajar antara guru dan siswa dalam kelas.

Penelitian yang dilakukan Aunurrahman dan Thamrin (2012) dengan judul "Hubungan Kompetensi Pedagogik dan Kompetensi Kepribadian dengan Kinerja Guru. Hasil penelitian ini bertujuan untuk mengungkap hubungan kompetensi pedagogik dan kompetensi kepribadian dengan kinerja guru baik secara parsial maupun simultan.
Kemampuan dan berbagai keterampilan yang dimiliki guru mempunyai hubungan yang erat dengan kinerja guru. Sikap guru yang merupakan evaluasi dari afektif diri guru tersebut akan terus berusaha untuk berperilaku supaya prestasi kerjanya makin bagus dengan meningkatnya kinerja guru. Menurut Uyoh, dkk (2010) guru yang berkompetensi tinggi adalah guru yang mempunyai kemampuan lebih dibanding dengan guru lain sehingga keberadaannya selalu dibutuhkan oleh siswa. Kemampuan-kemapuan guru dalam bekerja tercermin pada kinerja guru. Guru yang mempunyai kinerja yang baik akan mampu untuk menguasai karakteristik siswa, menguasai teori belajar, memfasilitasi potensi siswa, dan berkomunikasi dengan baik. Guru yang mempunyai kinerja baik akan secara tidak langsung kinerjanya menjadi meningkat dan maksimal, sehingga tujuan pembelajaran dapat tercapai. Hal tersebut juga akan berdampak baik bagi visi dan misi sekolah.

Guru yang memiliki kompetensi pedagogik dalam pengembangan kurikulum dan pengembangan kegiatan yang mendidik akan membuahkan kinerja yang baik dalam perencanaan pembelajaran. Guru yang memiliki kompetensi pedagogik dalam menguasai 
karakteristik siswa dan teori belajar serta dapat memfasilitasi atau sebagai penghubung potensi dan berkomunkasi yang baik maka guru tersebut menunjukkan kinerja yang bertanggung jawab pada pelaksanaan kegiatan yang aktif dan efektif. Hal tersebut selaras dengan teori Daryanto (2013), yaitu: kompetensi pedagogik guru merupakan kemampuan yang harus dimiliki guru berkenaan dengan karakteristik siswa. Guru yang memiliki kompetensi pedagogik pada evaluasi proses dan hasil belajar maka guru tersebut akan memiliki kinerja guru yang baik dan diwujudkan pada penilaian pembelajaran. Kemampuankemampuan guru tersebut di atas merupakan bagian dari kinerja guru dalam perencaan pembelajaran, pelaksanaan kegiatan pembelajaran yang aktif dan efktif serta penilaian pembelajaran (UndangUndang Nomor 14 T ahun 2005).

\section{KAJIAN TEORI}

\section{Kinerja Guru}

Menurut UU No 20 Tahun 2003 dan UU No 14 Tahun 2005 memberikan gambaran bahwa kinerja guru merupakan rumusan dalam melaksanakan tugas utama dan menunaikan beban kerja serta mewujudkan kompetensi dalam mengemban amanah pendidikan yang ada di pundaknya. Menurut Rivai (2004:309), kinerja guru adalah: perilaku nyata yang ditampilkan oleh guru sebagai prestasi kerja berdasarkan standar yang ditetapkan dan sesuai dengan perannya di sekolah.

Peran guru yang dimaksud adalah berkaitan dengan peran guru dalam proses pembelajaran. Guru merupakan faktor penentu yang sangat dominan dalam pendidikan pada umumnya, karena guru memegang peranan dalam proses pembelajaran, dimana proses pembelajaran merupakan inti dari proses pendidikan secara keseluruhan. Guru merupakan perencana, pelaksana sekaligus sebagai evaluator pembelajaran di kelas (Gunawan dalam Ondi Saondi, 2005).

Dari uraian diatas penulis dapat menyimpulkan bahwa pada hakikatnya kinerja guru adalah perilaku yang dihasilkan seorang guru dalam melaksanakan tugasnya sebagai pendidik dan pengajar ketika mengajar di depan kelas, sesuai dengan kriteria tertentu seperti perencanaan program pengajaran, pelaksanaan kegiatan pembelajaran dan evaluasi hasil pembelajaran. Kinerja seseorang guru akan nampak pada situasi dan kondisi kerja sehari-hari dalam aspek kegiatan menjalankan tugas dan cara/kualitas dalam melaksanakan kegiatan/tugas tersebut.

Kisi-kisi penilaian kinerja guru kelas atau mata pelajaran dalam buku 
Pedoman Pelaksanaan Penilaian Kinerja Guru (PK Guru) menurut Badan Pengembangan Sumber Daya Manusia Pendidikan dan Kebudayaan Penjaminan Mutu Pendidikan Tahun 2012 sebagai berikut: (a) perencanaan pembelajaran meliputi : (1) guru memformulasikan tujuan pembelajaran dalam RPP sesuai dengan kurikulum/silabus dan memperhatikan karakteristik siswa, (2) guru menyusun bahan ajar secara runut, logis, kontekstual dan mutakhir, (3) guru merencanakan kegiatan pembelajaran yang efektif, dan (4) guru memilih sumber belajar/ media pembelajaran sesuai dengan materi dan strategi pembelajaran. (b) pelaksanaan kegiatan pembelajaran yang aktif dan efektif meliputi : (1) guru memulai pembelajaran dengan efektif, (2) guru menguasai materi pelajaran, (3) guru menerapkan pendekatan/strategi pembelajaran yang efektif, (4) guru memanfaatan sumber belajar/media dalam pembelajaran, (5) guru memicu dan atau memelihara keterlibatan siswa dalam pembelajaran, (6) guru menggunakan bahasa yang benar dan tepat dalam pembelajaran, dan (7) guru mengakhiri pembelajaran dengan efektif. (c) penilaian pembelajaran meliputi: (1) guru merancang alat evaluasi untuk mengukur kemajuan dan keberhasilan belajar siswa. (2) guru menggunakan berbagai strategi dan metode penilaian untuk memantau kemajuan dan hasil belajar siswa dalam mencapai kompetensi tertentu sebagaimana yang tertulis dalam RPP, (3) guru memanfatkan berbagai hasil penilaian untuk memberikan umpan balik bagi siswa tentang kemajuan belajarnya dan bahan penyusunan rancangan pembelajaran selanjutnya.

Ada beberapa faktor yang mempengaruhi kinerja guru menurut Sudrajat (Djamarah, 2004) yaitu: kepribadian dan dedikasi, pengembangan profesi, kemampuan mengajar (kompetensi pedagogik), hubungan dan komunikasi, hubungan dengan masyarakat, kedisiplinan, kesejahteraan, dan iklim kerja. Berdasarkan beberapa faktor yang mempengaruhi kinerja guru tersebut, kompetensi pedagogik dan disiplin kerja merupakan faktor yang berpengaruh terhadap tinggi rendahnya kinerja guru.

Menurut Dita dkk kompetensi pedagogik erat hubungannya dengan kinerja guru. Guru yang mempunyai kompetensi pedagogik tinggi, maka kinerjanya pun akan tinggi. Hal ini karena penguasaan kompetensi pedagogik menunjukkan pemahaman guru terhadap kemampuan apa saja yang harus dimiliki dalam mengajar, sehingga ketika guru memahami hal itu akan berusaha menampilkan cara mengajar yang baik. 
Cara mengajar merupakan bentuk nyata kinerja guru. Dengan demikian penguasaan kompetensi pedagogik berhubungan dengan kualitas kinerjanya.

\section{Kompetensi Pedagogik}

Menurut Mulyasa

kompetensi pedagogik adalah seperangkat kemampuan yang berkaitan dengan interaksi belajar mengajar antara guru dan siswa dalam kelas. Menurut Daryanto (2013), definisi kompetensi pedagogik guru adalah merupakan kemampuan yang harus dimiliki guru berkenaan dengan karakteristik siswa dilihat dari berbagai aspek seperti moral, emosional, dan intelektual. Dengan demikian memungkinkan guru untuk membimbing siswa memenuhi standar kompetensi sesuai dengan Standar Nasional Pendidikan.

Menurut Undang-Undang Nomor 14 Tahun 2005 tentang Guru dan Dosen, kompetensi pedagogik adalah kemampuan pemahaman terhadap siswa, perancangan dan pelaksanaan pembelajaran, evaluasi hasil belajar, dan pengembangan siswa untuk mengaktualisasikan berbagai potensi yang dimilikinya.

Berdasarkan pendapat di atas dapat disimpulkan bahwa kompetensi pedagogik adalah kemampuan guru dalam mengelola siswa dan proses pembelajaran serta kemampuan mengembangkan kemampuan yang dimiliki oleh siswa.
Menurut Mendiknas (2007), aspekaspek kompetensi pedagogik adalah sebagai berikut: (a) guru mengidentifikasi karakteristik belajar siswa di kelasnya, (b) guru memastikan semua siswa mendapatkan kesempatan yang sama untuk berpartisipasi aktif dalam kegiatan pembelajaran, (c) guru menggunakan berbagai teknik untuk memotivasi kemauan belajar siswa, (d) guru selalu memastikan tingkat pemahaman siswa terhadap materi pembelajaran yang diajarkan, (e) guru dapat menyusun Silabus yang sesuai dengan kurikulum, (f) guru merancang rencana pembelajaran yang sesuai dengan silabus untuk membahas materi ajar agar siswa dapat menguasai kompetensi dasar yang ditetapkan, (g) guru mengelola kelas secara efektif tanpa mendominasi atau sibuk dengan kegiatannya sendiri, (h) guru menggunakan alat bantu mengajar untuk meningkatkan motivasi siswa, (i) guru menganalisis hasil belajar berdasarkan segala bentuk penilaian terhadap setiap siswa untuk mengetahui tingkat kemajuan masingmasing.

Berdasarkan tinjauan pustaka dalam penelitian ini, maka dapat diajukan hipotesis sebagai berikut: Terdapat hubungan positif antara kompetensi pedagogik dengan kinerja guru SD di UPTD PAUD dan DIKDAS Kecamatan 
Girimulyo Kabupaten Kulon Progo. Semakin tinggi kompetensi pedagogik maka semakin tinggi kinerja guru SD di UPTD PAUD dan DIKDAS Kecamatan Girimulyo Kabupaten Kulon Progo.

\section{METODE PENELITIAN}

Populasi dalam penelitian ini adalah semua guru SD se UPTD PAUD DIKDAS Kecamatan Girimulyo yang berjumlah 160 guru SD. Sampel adalah sebagian dari jumlah dan karakteristik yang dimiliki oleh populasi tersebut. Arikunto (1999) menyatakan bahwa apabila subjeknya kurang dari 100, diambil semua sekaligus sehingga penelitiannya merupakan penelitian populasi. Jika jumlah subjek besar maka diambil $10-15 \%$ atau $20-25 \%$ atau lebih.

Dalam penelitian ini peneliti mengambil sampel 25\% dari 160 guru yaitu sebanyak 40 guru SD. 40 guru SD tersebut akan diambil dari guru kelas UPTD PAUD DIKDAS Kecamatan Girimulyo. Teknik pengambilan sampel menggunakan teknik kelompok sampel, yaitu metode pemilihan suatu sampel dari kelompok-kelompok (cluster) dengan jumlah unit-unit elementer yang lebih kecil, setiap kelompok merupakan sub populasi yang bersama-sama membentuk populasi total (Soemarno, 2004).

Skala pengukuran yang digunakan dalam penelitian ini adalah modifikasi skala Likert, yaitu dari 1 sampai 4. Adapun penggunaan skala 1 - 4 untuk setiap jawaban responden selanjutnya dibagi ke dalam empat kategori yakni: Sangat Sesuai (SS), Sesuai (S), Tidak Sesuai (TS), dan Sangat Tidak Sesuai (STS).

Hasil uji validitas dan reliabilitas skala kompetensi pedagogik yang terdiri dari 69 item pernyataan tidak ada yang gugur. Nilai koefisien validitas item yang valid pada skala kompetensi pedagogik berkisar antara $0.305-0.861$. Hasil uji reliabilitas yang telah dilakukan dapat diketahui nilai alpha cronbach pada skala kompetensi pedagogik adalah sebesar 0.980. Skala kompetensi pedagogik mempunyai nilai alpha cronbach lebih besar dari 0.60, sehingga dapat dikatakan reliabel (Azwar, 1998).

Hasil uji validitas dan reliabilitas skala kinerja guru yang terdiri dari 27 item pernyataan tidak ada yang gugur. Nilai koefisien validitas item yang valid pada skala kinerja guru berkisar antara 0.437 0.908. Hasil uji reliabilitas yang telah dilakukan dapat diketahui nilai alpha cronbach pada skala kinerja guru adalah sebesar 0.964. Skala kinerja guru mempunyai nilai alpha cronbach lebih besar dari 0.60, sehingga dapat dikatakan reliabel (Azwar, 1998).

Analisis data menggunakan uji statistik korelasi product moment dan 
regresi ganda. Analisa korelasi product moment dan regresi ganda ini adalah analisis tentang hubungan antara satu dependent variable dengan dua atau lebih independent variable.

\section{HASIL DAN PEMBAHASAN}

Kategori hasil kompetensi pedagogik diketahui bahwa tidak ada subyek yang memiliki kompetensi pedagogik dengan klasifikasi rendah, untuk kategori sedang sebanyak 9 guru $(22,5 \%)$, dan dengan kategori tinggi sebanyak 31 guru $(77,5 \%)$. Hal tersebut menunjukkan bahwa guru yang memiliki kompetensi pedagogik cenderung pada klasifikasi tinggi. Kategori hasil kinerja guru diketahui bahwa tidak ada subyek yang memiliki kinerja dengan klasifikasi rendah, untuk kategori sedang sebanyak 6 guru (15\%), dan dengan kategori tinggi sebanyak 34 guru (85\%). Hal tersebut menunjukkan bahwa kinerja guru cenderung pada klasifikasi tinggi.

Uji normalitas digunakan untuk mengetahui apakah model regresi berdistribusi normal dengan membandingkan nilai probabilitas dengan nilai kritisnya 0.05 . Uji normalitas variabel kompetensi pedagogik diperoleh nilai KS$Z$ sebesar 0,132 dan $p=0,075(p>0,05)$ ini menunjukkan bahwa variabel kompetensi pedagogik memiliki sebaran normal. Uji normalitas variabel kinerja guru diperoleh nilai $\mathrm{KS}-\mathrm{Z}$ sebesar 0.128 dan $\mathrm{p}=0.095(\mathrm{p}>0.05)$ ini menunjukkan bahwa variabel kinerja guru memiliki sebaran normal.

Uji linearitas dilakukan untuk mengetahui apakah variabel yang dianalisis korelasinya memiliki hubungan linear. Pedoman yang digunakan untuk menguji linearitas garis regresi dilakukan dengan jalan menguji signifikansi $\mathrm{p}<0.05$. Adapun hubungan yang linear antara variabel kompetensi pedagogik dengan kinerja guru mengahasilkan nilai signifikansi $0.001(\mathrm{p} \leq 0.05)$.

Berdasarkan hasil uji korelasi dapat diketahui bahwa variabel kompetensi pedagogik besarnya korelasi atau nilai $\mathrm{r}=$ 0,497, apabila dikuadradkan $\left(\mathrm{r}^{2}\right)$ menjadi 0,247 , sedangkan nilai $\mathrm{p}=0,01$, sehingga $\mathrm{p}<0.05$. koefisien determinansi $\left(\mathrm{r}^{2}\right)$ sebesar 0,247, ini menunjukkan bahwa hipotesis 1 diterima dan kompetensi pedagogik memberikan sumbangan efektif terhadap kinerja guru sebesar 24,70\%, sedangkan sisanya sebesar $75,30 \%$ dipengaruhi variabel lain.

\section{PEMBAHASAN}

Hipotesis penelitian menyatakan ada hubungan signifikan dan positif antara kompetensi pedagogik dengan kinerja guru SD di Unit Pelaksana Teknis Daerah Pendidikan Anak Usia Dini dan 
Pendidikan Dasar Kecamatan Girimulyo Kabupaten Kulon Progo dalam penelitian ini diterima. Dengan kata lain, dapat diartikan bahwa semakin tinggi kompetensi pedagogik semakin tinggi pula kinerja guru. Sebaliknya, semakin rendah kompetensi pedagogik semakin rendah pula kinerja guru. Dengan demikian kompetensi pedagogik terbukti secara empirik mempengaruhi kinerja guru.

Pada penelitian ini, kompetensi pedagogik memberikan sumbangan efektif terhadap kinerja pada guru sebesar $24.70 \%$, sedangkan sisanya sebesar $75,30 \%$ dipengaruhi variabel lain seperti kepribadian dan dedikasi, pengembangan profesi, hubungan dan komunikasi, hubungan dengan masyarakat, disiplin kerja, kesejahteraan, dan iklim kerja pembelajaran (Muhlisin, 2009).

Variabel lain yang dimaksud pada penelitian ini adalah workshop Pendamping Implementasi Kurikulum 2013 dan workshop Implementasi Model Pembelajaran dalam Kurikulum 2013 serta adanya penelitian kinerja guru dalam instrumen A yang berbunyi Menyelenggarakan proses pembelajaran adalah merencanakan dan melaksanakan, mengevaluasi dan menilai hasil pembelajaran, dan melaksanakan tindak lanjut hasil penelitian. (Lampiran Peraturan Bersama Menteri Pendidikan Nasional dan kepala Bidang Kepegawaian Negara Nomor 03/IV/PB/2010. Nomor 14 Tahun 2010 Tanggal 6 Mei 2010).

Ditinjau dari aspek-aspek kompetensi pedagogik tampak bahwa aspek-aspek tersebut mampu mendukung dan meningkatkan kinerja guru. Sebagai contoh, aspek pengembangan kurikulum dan pengembangan kegiatan yang mendidik yang merupakan dua dari tujuh aspek kompetensi pedagogik pada penelitian ini, sangat mendukung aspek perencanaan pembelajaran dalam kinerja guru. Hal ini karena untuk dapat merencanakan pembelajaran yang baik, guru harus memahami dan memiliki kemampuan dalam mengembangkan kurikulum yang berlaku pada tingkat pembelajaran secara rasional dan operasional. Demikian juga perencanaan pembelajaran yang baik dapat terwujud jika guru mampu mengembangkan kegiatan-kegiatan pembelajaran yang bertujuan mendidik siswa (Robandi, 2007). Kinerja guru pada aspek pelaksanaan kegiatan pembelajaran yang aktif dan efektif sangat memerlukan dukungan kompetensi pedagogik, seperti ditunjukkan pada aspek menguasai karakter siswa dan teori belajar, memfasilitasi pengembangan potensi siswa, dan komunikasi. Dengan menguasai karakteristik siswa, baik dari aspek fisik, 
moral, sosial, kultural, emosional, dan intelektual, maka seorang guru akan dapat melaksanakan proses pembelajaran menjadi lebih baik, karena semua aktivitas disesuaikan dengan kondisi siswa. Demikian pula dengan menguasai teori belajar dan prinsip-prinsip pembelajaran yang mendidik, guru dapat memaknai perannya sebagai pengajar sekaligus pendidik yang baik, sehingga dapat menyampaikan materi pembelajaran dengan teknik yang mengacu pada teori belajar tertentu, dan juga menyisipkan penanaman karakter bagi anak didiknya, Daryanto (2013).

Sesuai dengan perannya saat ini, bahwa guru sebagai fasilitator dan motivator, maka ketika guru melaksanakan pembelajaran di kelas harus mampu menerapkan strategi pembelajaran yang mampu mengungkap potensi yang dimiliki siswa. Oleh karena itu guru harus memiliki kemampuan yang memadai untuk dapat menciptakan pembelajaran yang menarik dan menantang untuk menunjukkan kinerja yang sesuai dengan tuntutan kurikulum yang berlaku dan era pendidikan modern.

Kinerja guru dalam melaksanakan pembelajaran juga sangat memerlukan kemampuan berkomunikasi secara efektif, empatik, dan santun dengan siswa. Hal ini karena di era globalisasi saat ini memang diharapkan terjalin interaksi yang akrab dan hangat antara guru dan siswa, agar siswa merasa dekat dengan guru sehingga materi pelajaran dapat diterima lebih mudah. Tanpa empati dari guru, maka hubungan siswa dengan guru tidak lebih hanyalah hubungan antara pemberi pesan dan penerima pesan secara kaku, sehingga komunikasi edukatif tidak terjalin baik.

\section{SIMPULAN}

Berdasarkan hasil analisis data dan pembahasan yang telah dilakukan oleh peneliti, diperoleh hasil : Ada hubungan yang signifikan dan positif antara kompetensi pedagogik dan kinerja guru di Unit Pelaksana Teknis Daerah Pendidikan Anak Usia Dini dan Pendidikan Dasar Kecamatan Girimulyo Kabupaten Kulon Progo. Semakin tinggi kompetensi pedagogik semakin tinggi pula kinerja guru, sebaliknya semakin rendah kompetensi pedagogik semakin rendah pula kinerja guru tersebut. 


\section{DAFTAR PUSTAKA}

Arikunto, Suharsimi. (1993). Manajemen Pengajaran secara Manusiawi. Jakarta: PT. Rineka Cipta

Aunurrahman, dkk. (2013). Hubungan Kompetensi Pedagogik dan Kompetensi Kepribadian dengan Kinerja Guru. Pontianak: Universitas Tanjung Pura.

Azwar, S. (2000). Penyusunan Skala Psikologi. Yogyakarta: Pustaka Pelajar.

Daryanto. (2013). Standar Kompetensi dan Penilaian Kerja Guru Profesional. Yogyakarta: Gava Media.

Djamarah. (2000). Strategi Belajar Mengajar. Jakarta: Rineka Cipta. (2004). Strategi Belajar Mengajar. Jakarta: Rineka Cipta.
Mendiknas. (2007). Permendiknas RI No. 16 Tahun 2007 tentang Standar Kualifikasi Akademik dan Kompetensi Guru. DEPDIKNAS. (Permen16/2007KompetensiGuru.p df).

Robandi, B. (2012). Standar Kompetensi Guru Kelas SD/MI. Disajikan pada kegiatan PPM di UPTD Bale Endah Bandung.Pedagogik, FIP, UPI.

Sanjaya, W. (2005). Pembelajaran dalam Implementasi Kurikulum Brbasis Kompetensi. Jakarta: Kencana Prenada Media

Supriyadi, D. (1998). Mengangkat Citra dan Martabat Guru. Yogyakarta: Adicita Karya Nusa. 